7. The possible relationship of this reaction to mucopolysaccharide synthesis is discussed.

We are greatly indebted to Dr C. M. Mauritzen for kindly making available to us his equipment for the ultraviolet photography of paper chromatograms.

\section{REFERENCES}

Anand, N., Clark, V. M., Hall, R. H. \& Todd, A. R. (1952). J. chem. Soc. p. 3665.

Bandurski, R. S. \& Axelrod, B. (1951). J. biol. Chem. 193, 405.

Bernstein, S. \& McGilvery, R. W. (1952). J. biol. Chem. 199, 745.

Boström, H. \& Månsson, B. (1953). Acta chem. scand. 7, 1014.

Buchanan, J. G., Bassham, J. A., Benson, A. A., Bradley, D. F., Calvin, M., Daus, L. L., Goodman, M., Hayes, P. M., Lynch, V. H., Norris, L. T. \& Wilson, A. T. (1952). Phosphorus Metabolism, 2, 440, ed. by W. D. McElroy \& B. Glass. Baltimore: Johns Hopkins Press.

Cabib, E. \& Leloir, L. F. (1954). J. biol. Chem. 206, 779.

Cabib, E., Leloir, L. F. \& Cardini, C. E. (1953). J. biol. Chem. 203, 1055.

Caputto, R., Leloir, L. F., Cardini, C. E. \& Paladini, A. C. (1950). J. biol. Chem. 184, 333.

Chain, E. (1939). Biochem. J. 83, 407.

Chargaff, E., Magasanik, B., Vischer, E., Green, C., Doniger, R. \& Elson, D. (1950). J. biol. Chem. 186, 51.

Christie, S. M. H., Elmore, D. T., Kenner, G. W., Todd, A. R. \& Weymouth, F. J. (1953). J. chem. Soc. p. 2947.

Cohen, S. S. \& Scott, D. B. M. (1950). Science, 111, 543.

Cohn, W. E. \& Carter, C. E. (1950). J. Amer. chem. Soc. 72, 4273.

Durrum, E. L. (1950). J. Amer. chem. Soc. 72, 2943.

Dutton, G.J.\& Storey, I. D.E. (1951). Biochem.J.48, xxix.

Dutton, G. J. \& Storey, I. D. E. (1953). Biochem. J. 53, xxxvii.

Dutton, G. J. \& Storey, I. D. E. (1954). Biochem. J. 57, 275. Fiske, C. H. \& Subbarow, Y. (1925). J. biol. Chem. 66, 375. Fitting, C. \& Doudoroff, M. (1952). J. biol. Chem. 199, 153. Folin, O. \& Malmros, H. (1929). J. biol. Chem. 83, 115.

Gulland, J. M. \& Jackson, E. M. (1938). Biochem. J. 32, 597.
Hanes, C. S. \& Isherwood, F. A. (1949). Nature, Lond., 164, 1107.

Hotchkiss, R. D. (1948). J. biol. Chem. 175, 315.

Hurlbert, R. B. \& Potter, V. R. (1954). J. biol. Chem. 209, 1. Johnson, M., Kaye, M. A. G., Hems, R. \& Krebs, H. A. (1953). Biochem. J. 54, 625.

Kalckar, H. M. (1953). Biochim. biophys. Acta, 12, 250.

Kalckar, H. M. (1954). Science, 119, 479.

King, E. J. (1946). Micro-Analysis in Medical Biochemistry, p. 53. London: Churchill.

Kornberg, A. \& Pricer, W. E. (1950). J. biol. Chem. 182, 763.

Leloir, L. F. \& Cabib, E. (1953). J. Amer. chem. Soc. 75, 5445.

Leloir, L. F. \& Cardini, C. E. (1953). J. Amer. chem. Soc. 75, 6084.

LePage, G. A. \& Umbreit, W. W. (1945). Manometric Techniques, lst ed., p. 160, ed. by W. W. Umbreit, R. H. Burris \& J. F. Stauffer. Minneapolis: Burgess Publishing Co.

Levvy, G. A. (1952). Science, 116, 285.

Levvy, G. A. (1953). Brit. med. Bull. 9, 126.

Markham, R. \& Smith, J. D. (1949). Biochem. J. 45, 294.

Markham, R. \& Smith, J. D. (1951). Biochem. J. 49, 407.

Paladini, A. C. \& Leloir, L. F. (1952). Biochem. J. 51, 426.

Park, J. T. (1952a). 'J. biol. Chem. 194, 877.

Park, J. T. (1952b). J. biol. Chem. 194, 885.

Partridge, S. M. (1948). Biochem. J. 42, 238.

Partridge, S. M. (1949). Symp. biochem. Soc. 3, 52.

Paul, J. (1951). Ph.D. Thesis, University of Glasgow.

Ploeser, J. M. \& Loring, H. S. (1949). J. biol. Chem. 178, 431.

Rutter, W. J. \& Hansen, R. G. (1953). J. biol. Chem. 202, 323.

Schmitz, H., Potter, V. R., Hurlbert, R. B. \& White, D. M. (1954). Cancer Res. 14, 66.

Sie, H-G. \& Fishman, W. H. (1954). J. biol. Chem. 209, 73.

Smith, J. D. \& Markham, R. (1950). Biochem. J. 46, 509.

Smith, E. E. B. \& Mills, G. T. (1954). Biochim. biophys. Acta, 13, 386.

Storey, I. D. E. (1950). Biochem. J. 47, 212.

Trucco, R. E. (1951). Arch. Biochem. Biophys. 34, 482.

Videla, H. G. P. (1954). Cienc. e Invest. 10, 236.

Wyatt, G. R. (1951). Biochem. J. 48, 584.

Zeller, E. A. (1951). The Enzymes, 1, p. 1008, ed. by J. B. Sumner \& K. Myrbäck. New York: Academic Press.

\title{
Metabolism of Thyroid Hormones
}

\section{THE DEIODINATION OF THYROXINE AND TRIIODOTHYRONINE IN VITRO}

\author{
By W. E. SPROTT aNd N. F. MACLAGAN \\ Department of Chemical Pathology, Westminster Medical School (University of London), London, S.W. 1
}

(Received 11 August 1954)

Recent work on the occurrence and properties of 3:5:3'-triiodo-L-thyronine (Gross \& Pitt-Rivers, $1952 a, b, c$; Roche, Lissitzky \& Michel, 1952) strongly suggests that this substance is the active form of the thyroid hormone. On the other hand, it is well established that the main thyroid substance circulating in the blood is thyroxine (Harington, 1944; Taurog \& Chaikoff, 1948; Laidlaw, 1949;
Leblond \& Gross, 1949). It therefore seems necessary to postulate the conversion of thyroxine into triiodothyronine in the peripheral tissues, a process which has not been demonstrated with certainty. Earlier work in this field has recently been reviewed (Maclagan \& Wilkinson, 1952; Roche \& Michel, 1954) and during the preparation of this paper a more definite claim has been made by 
Albright, Larson \& Tust (1954), who reported chromatographic evidence for the conversion of thyroxine into triiodothyronine in rat-kidney slices.

One result of this conversion would be the deiodination of thyroxine, and work on this subject is therefore of interest at the present time. There is abundant evidence for such deiodination in whole animals, both intact and thyroidectomized (Elmer, 1938; Gross \& Leblond, 1951 ; Maclagan \& Wilkinson, 1954). In contrast to this, no successful experiments on isolated tissues have been reported, although the deiodination of diiodotyrosine in tissue-slice preparations was shown by Hartmann (1950), and similar results with mono- and diiodotyrosine were obtained by Roche, Michel, Michel \& Lissitzky (1951). These preparations had no action on thyroxine.

The probable conversion of thyroxine into triiodothyronine was also indicated by our work on antithyroxine compounds such as butyl 4-hydroxy3:5-diiodobenzoate (BHDB). BHDB inhibits the metabolic effects of thyroxine while augmenting those of triiodothyronine (Maclagan, Sprott \& Wilkinson, 1952). It also inhibits the deiodination of both compounds in intact and probably in thyroidectomized animals (Wilkinson, Sprott, Bowden \& Maclagan, 1954; Wilkinson \& Feetham, 1954). These results are readily explained if we assume that BHDB acts by interference with the conversion of thyroxine into triiodothyronine and also with the destruction of triiodothyronine in the body, a process presumably involving further deiodination.

Further evidence was sought in a study of the deiodination of thyroxine by in vitro methods, and the present communication presents fresh facts on this subject. A preliminary account has appeared elsewhere (Maclagan \& Sprott, 1954).

\section{MATERIALS AND METHODS}

Tissues. The tissues were obtained from male albino rats weighing $200-300 \mathrm{~g}$. The animals were killed by a blow on the head and the required organs removed without delay, placed in ice-cold $1.15 \%(\mathrm{w} / \mathrm{v}) \mathrm{KCl}(10 \mathrm{ml} . / \mathrm{g}$. tissue) and comminuted in an 'Atomix' homogenizer for $1 \mathrm{~min}$. The homogenates were filtered through cotton wool before use.

Substrates. Sodium L-thyroxine and sodium triiodo-Lthyronine were supplied by Glaxo Laboratories Ltd., and radioactive $\mathrm{L}$-thyroxine, labelled in positions $3^{\prime}$ and $5^{\prime}$ with 131I, was purchased from the Radiochemical Centre, Amersham. It had an initial specific radioactivity of $1.05 \mu \mathrm{c} / \mu \mathrm{g}$. Non-radioactive thyroxine and triiodothyronine were $0.1 \%(\mathrm{w} / \mathrm{v})$ solutions in a medium containing $0.0067 \mathrm{M}-\mathrm{Na}_{2} \mathrm{CO}_{3}$ and $0.06 \mathrm{M}-\mathrm{Na}_{2} \mathrm{HPO}_{4}$. The solution of radioactive thyroxine, in $50 \%(\mathrm{v} / \mathrm{v})$ propylene glycol (propane-1:2-diol) at $\mathrm{pH} 8$, was diluted with distilled water to yield a solution containing $4 \mu \mathrm{g}$. substrate $/ \mathrm{ml}$.
The purity of substrates was checked by paper chromatography using butanol-dioxan-ammonia (Gross, Leblond, Franklin \& Quastel, 1950), the chromatograms being either treated with the ceric sulphate reagent of Bowden \& Maclagan (1954) or examined by autoradiography.

Buffers. The buffer solutions employed in this work were $0.067 \mathrm{M}$ sodium phosphate, $0.1 \mathrm{M}$ glycine in $0.1 \mathrm{M}-\mathrm{NaCl}$ and $0 \cdot 1 \mathrm{M}$ sodium citrate. In experiments with non-radioactive thyroxine or triiodothyronine (' $\mathrm{N}$ ' systems), homogenate (10 ml.), buffer $(10 \mathrm{ml}$.) and substrate solution $(5 \mathrm{ml}$.) were incubated at $37^{\circ}$ in $50 \mathrm{ml}$. conical flasks in a Braun rotary Warburg apparatus (Shandon Scientific Co., 6 Cromwell Place, London, S.W. 7). In experiments with labelled thyroxine (' $R$ ' systems), homogenate ( $5 \mathrm{ml}$.), buffer (5 ml.) and thyroxine solution $(1 \mathrm{ml}$.) were incubated in conical flasks of $25 \mathrm{ml}$. capacity. The resulting $\mathrm{pH}$ of the complete system was measured with a glass electrode (Marconi Instruments Ltd., St Albans, Herts) before incubation.

Measurement of deiodination. After incubation, $4 \mathrm{ml}$. of $10 \%(v / v)$ horse serum were added to each ' $R$ ' system followed by $5 \mathrm{ml}$. of $25 \%$ (w/v) trichloroacetic acid (TCA). After standing $5 \mathrm{~min}$. the mixture was filtered through a Whatman no. 50 paper and a suitable sample, usually $2 \mathrm{ml}$., was diluted to $10 \mathrm{ml}$. with carrier iodide solution and counted in the liquid Geiger-Müller counter of Veall (1948).

' $N$ ' systems were each treated with $10 \mathrm{ml}$. of $25 \%$ TCA and filtered after $5 \mathrm{~min}$. The precipitates were then washed twice with $5 \%$ (w/v) TCA (5 ml.). The iodide content of the combined filtrates was estimated by electrometric titration with the $\mathrm{Ag} / \mathrm{Ag}_{2} \mathrm{~S}$ electrode as previously described (Wilkinson et al. 1954).

\section{RESULTS}

\section{' $N$ ' systems}

These experiments were conducted only with liver homogenates. Our initial attempts were thought to be negative, because near neutrality the amount of iodide produced was small and was unaffected by preliminary heating to $100^{\circ}$ for $30 \mathrm{~min}$. Later, however, it was found that much greater amounts of iodide were formed at acid and alkaline reactions, and that the system could be effectively inhibited by heating for $30 \mathrm{~min}$. in the presence of trichloroacetic acid. The most practical control was, however, to precipitate with trichloroacetic acid and filter immediately after the addition of thyroxine, when only minimal amounts of iodide were found. Fig. 1 shows the results of a typical experiment conducted in this way, from which it will be seen that the deiodination of thyroxine showed two optima at $\mathrm{pH} 3.5$ and 9.5 , while in the case of triiodothyronine a single optimum at $\mathrm{pH} 9.5$ was observed. Up to $18 \%$ deiodination was recorded in the case of thyroxine, expressed as percentage of total substrate iodine, corresponding to the substantial liberation of $\mathbf{0 . 6} \mathrm{mg}$. of iodide. Triiodothyronine was deiodinated somewhat less effectively (up to $7 \%$ ). It may be noted here that the accuracy of the electrometric titration for iodide is about $\pm 5 \mu \mathrm{g}$. 


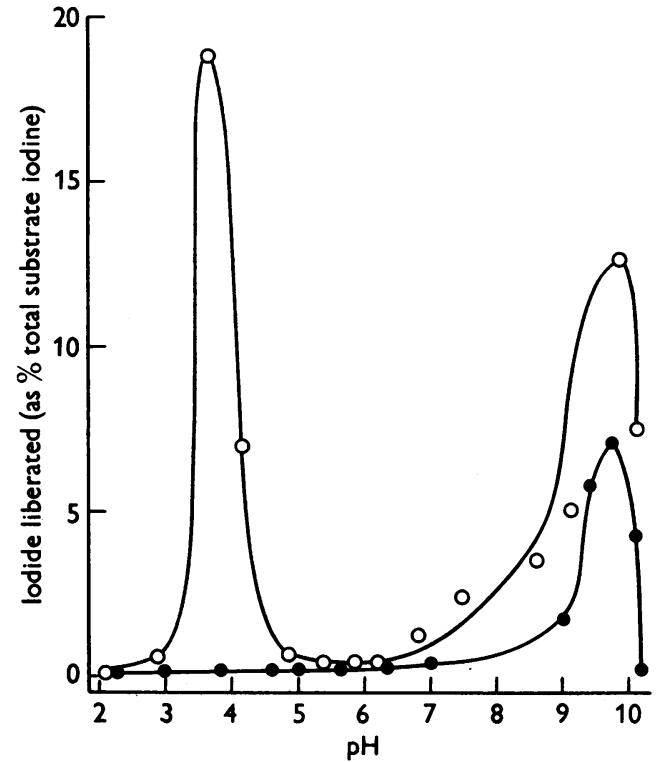

Fig. 1. Effect of $\mathrm{pH}$ upon deiodination of $\mathrm{L}$-thyroxine $(5 \mathrm{mg}$.$) and triiodo-L-thyronine (5 \mathrm{mg}$.) by rat-liver homogenates in presence of citrate after $18 \mathrm{hr}$. $\mathrm{O}, \mathrm{L}$ Thyroxine; 9 , triiodo-L-thyronine.

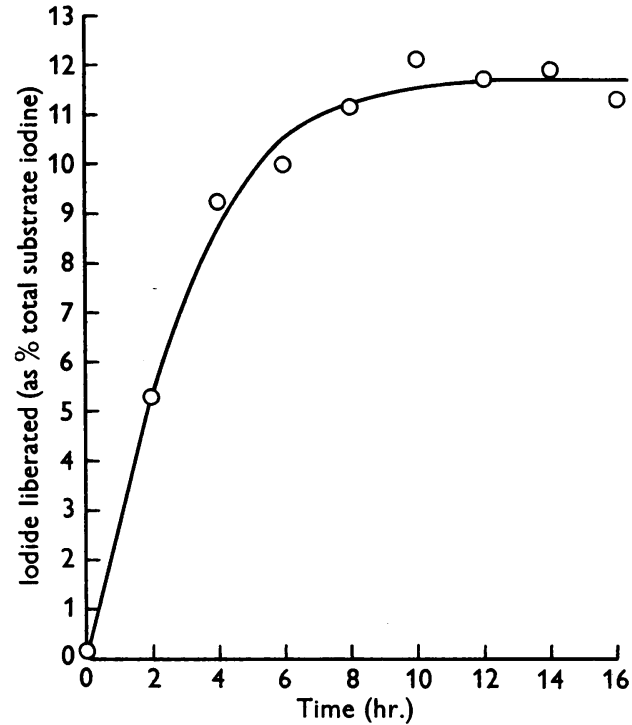

Fig. 2. Rate of deiodination of $\mathrm{L}$-thyroxine $(5 \mathrm{mg}$.) by rat-liver homogenate in glycine buffer at $\mathrm{pH} 9 \cdot 3$.

Table 1. Effect of inhibitors on deiodination of L-thyroxine and triiodo-L-thyronine in ' $N$ ' systems

$5 \mathrm{mg}$. substrate incubated in glycine buffer, for $18 \mathrm{hr}$. HEHDB, $\beta$-hydroxyethyl 4-hydroxy-3:5-diiodobenzoate.

\begin{tabular}{|c|c|c|c|c|}
\hline \multirow[b]{2}{*}{ Substrate } & \multirow[b]{2}{*}{ pH } & \multirow[b]{2}{*}{ Inhibitor } & \multicolumn{2}{|c|}{$\begin{array}{l}\text { Duplicate estimations of } \\
\text { iodide produced ( } \mu \mathrm{g} .)\end{array}$} \\
\hline & & & $\begin{array}{l}\text { Without } \\
\text { inhibitor }\end{array}$ & $\begin{array}{c}\text { With } \\
\text { inhibitor }\end{array}$ \\
\hline Na L-thyroxine & $9 \cdot 8$ & $\begin{array}{l}\text { Absence of air } \\
\left.\text { ( } \mathrm{N}_{\mathrm{z}} \text { atmosphere }\right)\end{array}$ & 376,445 & 128,193 \\
\hline $\begin{array}{l}\text { Na L-thyroxine } \\
\text { Na L-thyroxine } \\
\text { Na L-thyroxine } \\
\text { Na triiodo-L-thyronine } \\
\text { Na triiodo-L-thyronine }\end{array}$ & $\begin{array}{l}\mathbf{8 \cdot 0} \\
9 \cdot 3 \\
9 \cdot 3 \\
9 \cdot 3 \\
9 \cdot 3\end{array}$ & $\begin{array}{l}\text { KCN, } 8 \times 10^{-6} \mathrm{M} \\
\text { BHDB, } 10^{-8_{M}} \\
\text { HEHDB, } 10^{-8_{M}} \\
\text { BHDB, } 10^{-8_{M}} \\
\text { HEHDB, } 10^{-8_{M}}\end{array}$ & $\begin{array}{l}170,141 \\
354,370 \\
354,370 \\
121,130 \\
121,130\end{array}$ & $\begin{array}{r}86,99 \\
432,424 \\
384,412 \\
114,134 \\
134,120\end{array}$ \\
\hline
\end{tabular}

Table 2. Deiodination of ${ }^{181} \mathrm{I}$-labelled $\mathrm{L}$-thyroxine in various buffers

$4 \mu \mathrm{g}$. substrate incubated for $3 \mathrm{hr}$. Results expressed as percentage of substrate radioactivity. Control system with phosphate buffer at $\mathrm{pH} 6.1$ showed $8 \%$ deiodination at zero time.

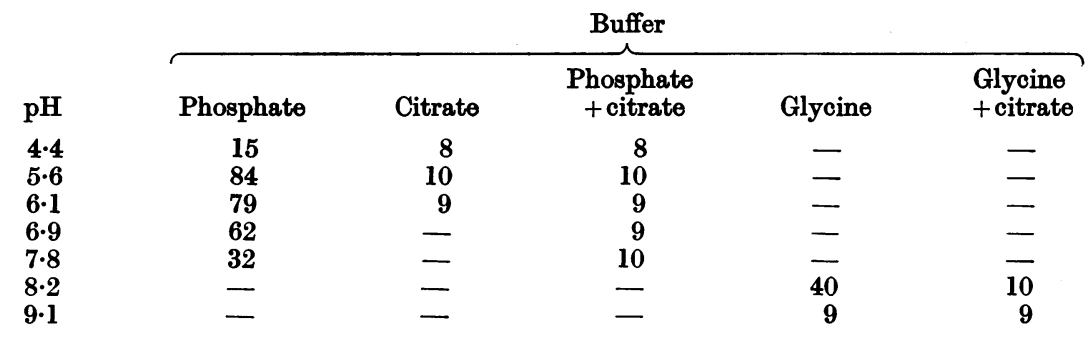


The finding of optimum deiodination at these two unphysiological $\mathrm{pH}$ levels suggests that the results may have been partly dependent on the limited solubility of both thyroxine and triiodothyronine in the neutral range. The amount of deiodination at physiological $\mathrm{pH}$ was in fact too small for accurate study by the method used.

The reaction is a fairly rapid one, as shown in Fig. 2. This experiment which was conducted at pH 9.3, shows appreciable deiodination after $2 \mathrm{hr}$., and maximal results after $8 \mathrm{hr}$.

The deiodination was considerably reduced by exclusion of air and by the presence of $8 \times 10^{-4} \mathrm{M}$ $\mathrm{KCN}$, but was not affected by antithyroxine substances (Table 1). While no direct comparison between citrate and other buffers was made, the results do not suggest that citrate was an inhibitor at pH 9.5 (cf. Fig. 1 and Table 1).

\section{' $R$ ' systems}

Deiodination by ' $R$ ' systems with rat-liver homogenate was found to be strongly inhibited by citrate, a factor which invalidated many of our earlier experiments. This is shown in Table 2, from which it will be seen that $0.1 \mathrm{M}$ sodium citrate inhibits almost completely at all reactions between pH 4.4 and 8.3. At higher $\mathrm{pH}$ values $(9 \cdot 15)$ the deiodination was minimal and approached the control value.

In phosphate buffer the ' $R$ ' system showed a broad pH optimum between $\mathrm{pH} 5$ and 7 (Fig. 3). It will be seen that considerably greater percentage

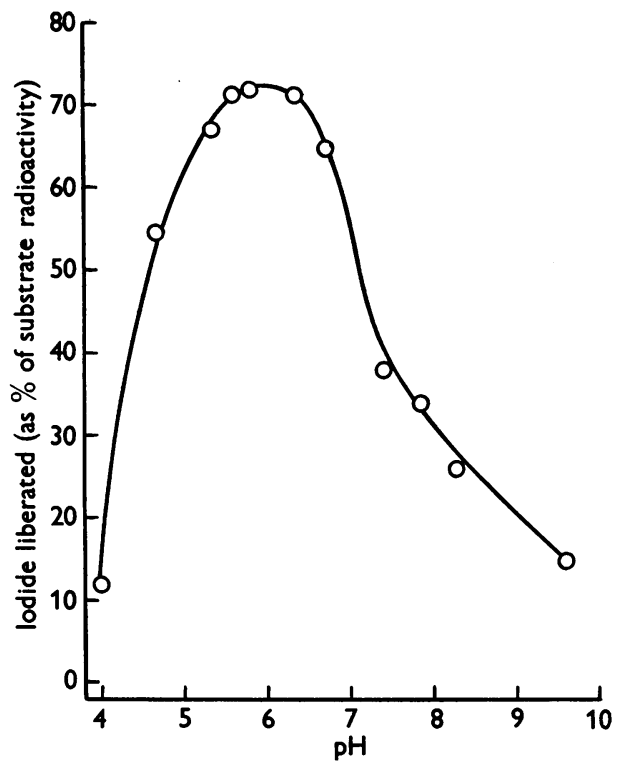

Fig. 3. Effect of $\mathrm{pH}$ upon deiodination of 181I-labelled L-thyroxine (4 $\mu \mathrm{g}$.) by rat-liver homogenate in phosphate buffer at pH 6 in $3 \mathrm{hr}$. deiodination was observed in ' $R$ ' systems (up to $72 \%$ ) than in ' $N$ ' systems. However, the results are not directly comparable, since the radioactive method measures only the liberation of the $3^{\prime}$ and $5^{\prime}$ iodine atoms, the results being expressed as percentage of substrate radioactivity. Furthermore,

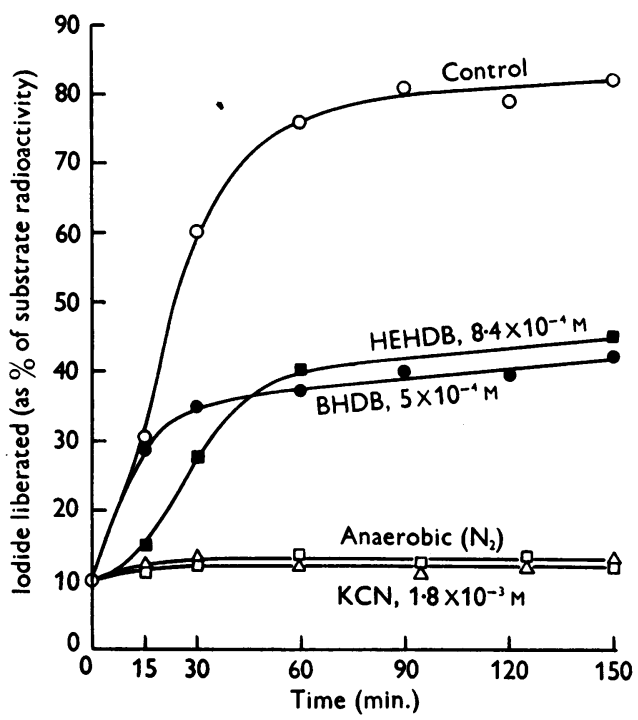

Fig. 4. Effect of inhibitors on rate of deiodination of ${ }^{131} \mathrm{I}$. labelled L-thyroxine (4 $\mu$ g.) by rat-liver homogenate in phosphate buffer at pH 6.0.

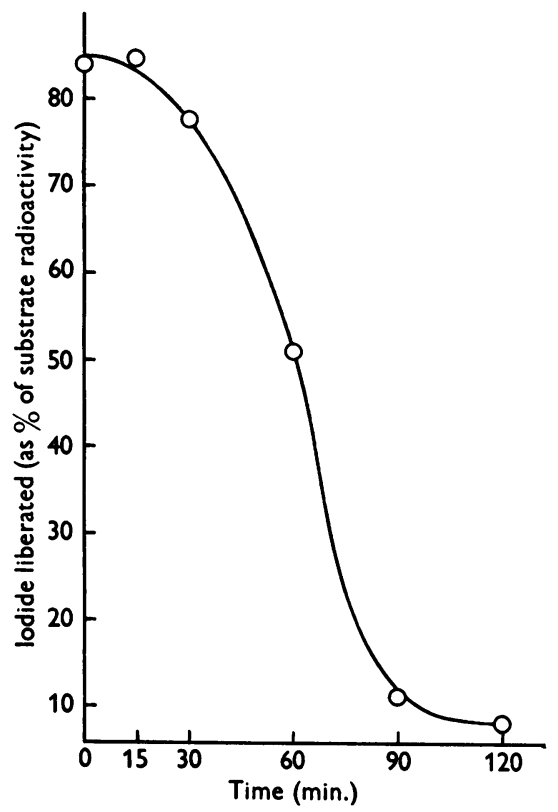

Fig. 5. Effect of heating at $100^{\circ}$ on deiodination of ${ }^{131} \mathrm{I}$ labelled L-thyroxine (4 $\mu \mathrm{g}$.) by rat-liver homogenate in phosphate buffer at $\mathrm{pH} 6$ (3 hr. incubation). 
the concentration of substrate in the ' $R$ ' systems is lower by a factor of approximately 1000 .

Fig. 4 shows the effect of inhibitors on the rate of deiodination. It may be noted that since the thyroxine was labelled only in the $3^{\prime}$ and $5^{\prime}$ positions, any deiodination in excess of $50 \%$ presumably indicates breakdown beyond the triiodothyronine stage.

It will be seen that the system was completely inhibited by exclusion of air or by the presence of cyanide. Two typical antithyroxine compounds BHDB, and $\beta$-hydroxyethyl 4-hydroxy-3:5-diiodobenzoate (HEHDB) produced about $50 \%$ inhibition of deiodination. This substantial inhibition accords well with our theories of the mode of action of these substances (see Introduction and Discussion).

The ' $R$ ' system resembled the ' $N$ ' system in its resistance to inactivation by heating. It will be seen from Fig. 5 that very little inactivation occurred at $100^{\circ}$ in $30 \mathrm{~min}$., but heating for $2 \mathrm{hr}$. inactivated the system completely.

\section{Other tissues}

The ' $R$ ' system was also investigated in homogenates from various other organs with the results shown in Table 3. It will be seen that some deiodination was observed in all tissues studied. Results were maximal with liver and minimal with intestinal mucosa, with the thyroid gland showing only feeble activity.

Table 3. Deiodination of ${ }^{131} \mathrm{I}$-labelled L-thyroxine (4 $\mu$ g.) by rat-tissue homogenates at $\mathrm{pH} 6 \cdot 0$

Incubation for $3 \mathrm{hr}$. in phosphate buffer.

\begin{tabular}{lcc} 
& & Radioactive iodide liberated as \\
\cline { 2 - 3 } & Organ & $\begin{array}{c}\text { Percentage } \\
\text { of substrate } \\
\text { radioactivity }\end{array}$ \\
Liver & 27035 & 69 \\
Kidney & 27395 & 70 \\
Spleen & 17080 & 44 \\
& 16550 & 42 \\
Brain & 15755 & 40 \\
Muscle & 16390 & 42 \\
& 16790 & 43 \\
Adrenal & 16410 & 42 \\
Thyroid & 15800 & 40 \\
Intestinal mucosa & 14830 & 38 \\
Control (liver homogenate & 14070 & 36 \\
at zero time) & 9360 & 24 \\
& 7210 & 18
\end{tabular}

\section{Fate of thyroxine residues}

Numerous attempts were made to identify other products of the reaction by investigating the trichloroacetic acid precipitates from experiments in which active deiodination had occurred. The thyronine derivatives were extracted with $n$ butanol, sometimes after preliminary solution of the precipitate in a few drops of ammonia (sp.gr. 0.880), and the extract was submitted to paper chromatography. With ' $N$ ' systems the chromatograms were developed by the ceric sulphate method but the preponderance of unaltered thyroxine prevented the definite identification of other spots. In the ' $R$ ' systems triiodothyronine (18 $\mu$ g.) was added as carrier before extraction and radioautographs were made. Unfortunately this was done after the main series of experiments at a time when some triiodothyronine had already resulted from spontaneous

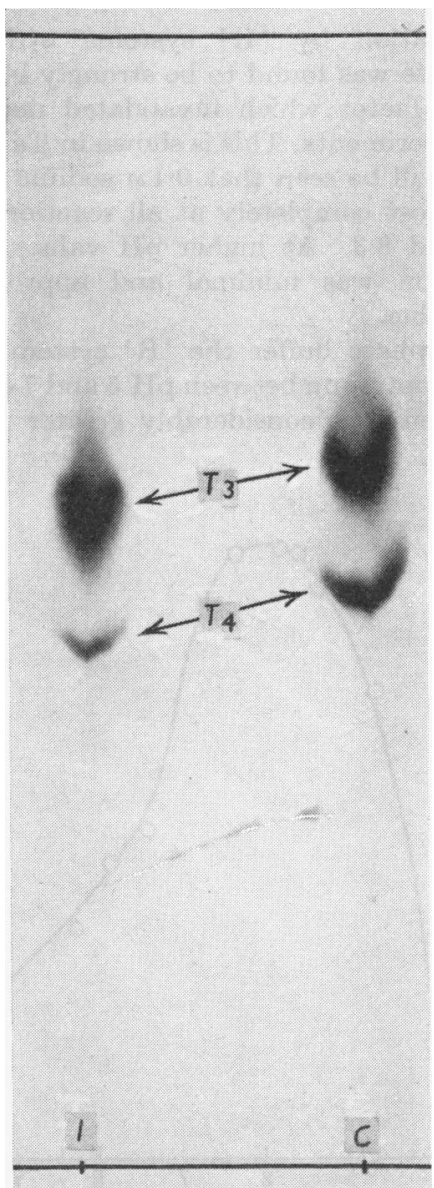

Fig. 6. Radioautograph of $n$-butanol extracts from rat-liver homogenates incubated with ${ }^{131} \mathrm{I}$-labelled thyroxine in phosphate buffer at $\mathrm{pH} 6.0$ for $2 \mathrm{hr}$. $C=$ control; $I=$ incubated; $T_{4}=$ thyroxine; $T_{3}=$ triiodothyronine. 
decomposition of the labelled thyroxine which, as previously noted, does not keep well in solution (Wilkinson et al. 1954). The results are shown in Fig. 6, from which it will be seen that incubation has diminished the amounts both of thyroxine and of triiodothyronine present, but the ratio of triiodothyronine to thyroxine appears definitely higher in the incubated extract. The results would be consistent with the conversion of thyroxine into triiodothyronine and the later decomposition of the latter to a non-radioactive product.

\section{DISCUSSION}

The experiments recorded appear to establish the existence in the rat of enzyme systems of wide distribution capable of removing iodine from $L$ thyroxine and from triiodo-L-thyronine.

The evidence suggests the presence of two different aerobic heat-resistant systems which we have called for convenience ' $R$ ' and ' $N$ '. System ' $R$ ', which was demonstrated with labelled thyroxine (4 $\mu \mathrm{g}$. per system) had optimum activity at about $\mathrm{pH} 6$ and was inhibited by citrate and by antithyroxine compounds. System ' $N$ ', demonstrated with higher concentrations of unlabelled thyroxine (5 mg. per system), had two regions of optimum activity at pH 3.5 and 9.5 and was not inhibited by citrate or by antithyroxine compounds. This system also attacked triiodothyronine at pH 9.5.

System ' $N$ ' has only been investigated in liver homogenates but system ' $R$ ' was found in all organs tested, being most active in the liver. Although the two systems appear to have these important differences it should be borne in mind that they have been investigated, of necessity, at entirely different levels of substrate concentration, so that the distinction may be more apparent than real.

The product of the deiodination of thyroxine has not been established with certainty but it may be triiodothyronine. Since this substance is itself attacked by the same system, the difficulties of demonstrating its presence are obvious. In this connexion it may be noted that the evidence produced by Albright et al. (1954) depended purely on the intensity and position of the radioactivity on paper chromatograms. No autoradiographs of these were reproduced and the counting rates given for the triiodothyronine area were of the low order of $\mathbf{5 - 4 0}$ counts $/ \mathrm{min}$.

As was expected from our previous work, the ' $R$ ' deiodinating system was inhibited by antithyroxine compounds. This inhibition provides further evidence for our theory of the mode of action of these substances, which appears to depend directly upon this inhibition of deiodination (Maclagan et al. 1952).
The actual reactions involved in the deiodination are unknown and will need further study. The aerobic nature of the process and the inhibition by cyanide indicate that oxidative processes are involved, a conclusion which has to be reconciled with an overall reaction which is presumably one of reduction. Further unusual features are the marked inhibition by citrate and the heat-resistant nature of the system, which requires $2 \mathrm{hr}$. at $100^{\circ}$ for complete inactivation.

The ready deiodination observed under the condition of our experiments is somewhat surprising in view of the many previous unsuccessful attempts to demonstrate the process both by ourselves and by others. In our own work the principal stumbling blocks appear to have been the very limited solubility of thyroxine in the neutral range, the heatresistant nature of the system, and the inhibition by citrate. Thus, in the non-radioactive experiments convincingly positive results could only be obtained at reactions sufficiently acid or alkaline to dissolve the thyroxine. In many of the earlier experiments also the 'controls' were heated for only 30 min., when they showed no difference from the unheated incubated systems, such results being regarded as negative. The use of citrate buffers also probably accounted for many negative results.

It is hoped that the further study of these deiodinating systems will help to throw light upon the peripheral action of the thyroid hormone.

\section{SUMMARY}

1. Two aerobic partially heat-resistant systems which deiodinate L-thyroxine and triiodo-L-thyronine have been demonstrated in homogenates from the liver and other tissues of the rat.

2. ' $N$ ' systems, demonstrated with non-radioactive thyroxine and triiodothyronine, were effective at $\mathrm{pH} \mathrm{3.5}$ and at $\mathrm{pH} 9.5$. They were inhibited by cyanide and by exclusion of air but not by citrate or by antithyroxine compounds.

3. ' $R$ ' systems, demonstrated with ${ }^{131}$ I-labelled thyroxine, were effective at $\mathrm{pH} 6$ and were inhibited by cyanide, exclusion of air, citrate and antithyroxine compounds.

4. Some evidence was obtained for the conversion of thyroxine into triiodothyronine by ' $R$ ' systems.

5. The significance of these results is briefly discussed.

The work was aided by a grant from the Medical Research Council and from the Central Research Fund of the University of London to one of us (N.F.M.) and by grants from the Governors' Discretionary Fund of Westminster Hospital, which are gratefully acknowledged. We are also indebted to Mr A. J. Feetham and to Mr C. H. Bowden for valuable help, and to Miss Ann Burgess for technical assistance. The thyroxine and triiodothyronine were generously supplied by Glaxo Laboratories Ltd. 


\section{REFERENCES}

Albright, E. C., Larson, F. C. \& Tust, T. H. (1954). Proc. Soc. exp. Biol., N.Y., 86, 137.

Bowden, C. H. \& Maclagan, N. F. (1954). Biochem. J. 56, vii. Elmer, A. W. (1938). Iodine Metabolism and Thyroid Function. London: Oxford University Press.

Gross, J. \& Leblond, C. P. (1951). Endocrinology, 48, 714.

Gross, J., Leblond, C. P., Franklin, A. E. \& Quastel, J. H. (1950). Science, 111, 605.

Gross, J. \& Pitt-Rivers, R. (1952a). Lancet, 1, 439.

Gross, J. \& Pitt-Rivers, R. (1952b). Lancet, 1, 593.

Gross, J. \& Pitt-Rivers, R. (1952c). Lancet, 1, 766.

Harington, C. R. (1944). Proc. Roy. Soc. B, 132, 223.

Hartmann, N. (1950). Hoppe-Seyl. Z. 285, 1.

Laidlaw, J. C. (1949). Nature, Lond., 164, 927.

Leblond, C. P. \& Gross, J. (1949). J. clin. Endocrin. 9, 171.

Maclagan, N. F. \& Sprott, W. E. (1954). Lancet, 2, 368.
Maclagan, N. F., Sprott, W. E. \& Wilkinson, J. H. (1952). Lancet, 2, 915.

Maclagan, N. F. \& Wilkinson, J. H. (1952). Rep. Progr. Chem. 49, 291.

Maclagan, N. F. \& Wilkinson, J. H. (1954). J. Physiol. 125, 405.

Roche, J., Lissitzky, S. \& Michel, R. (1952). C.R. Acad. Sci., Paris, 234, 997.

Roche, J. \& Michel, R. (1954). Annu. Rev. Biochem. 23, 481.

Roche, J., Michel, R., Michel, O. \& Lissitzky, S. (1951). C.R. Soc. Biol., Paris, 145, 288.

Taurog, A. \& Chaikoff, I. L. (1948). J. biol. Chem. 176, 639.

Veall, N. (1948). Brit. J. Radiol. N.S. 21, 347.

Wilkinson, J. H. \& Feetham, A. J. (1954). J. Endrocrin. 11, vii.

Wilkinson, J. H., Sprott, W. E., Bowden, C. H. \& Maclagan, N. F. (1954). Biochem. J. 56, 215.

\title{
Separation of Oestrogens in Urinary Extracts by Partition Chromatography
}

\author{
By W. S. BAULD* \\ Department of Biochemistry, University of Edinburgh
}

(Received 30 March 1954)

In a method developed for the quantitative determination of oestrogens in urine (Bauld, 1954a) partition chromatography was applied to the separation and purification of oestrone and oestradiol-17 $\beta$. Selection of a suitable solvent system was based on the following considerations. The desirability of a system with the oestrogens partitioning markedly in favour of the stationary phase is obvious from a rearrangement of the equation of Butt, Morris, Morris \& Williams (1951) to express retention volume in terms of the other factors. In addition, for a routine method it is preferable to have the oestrogens freely soluble in one or other of the phases. Investigation of the contaminants of the oestrone-oestradiol-17 $\beta$ fraction of male urinary extracts (Bauld, 1954a) showed the presence of acidic and basic material, and this made it desirable to have aqueous alkali as the stationary phase. Carol, Haenni \& Banes (1950) reported the use of an aqueous sodium hydroxide-benzene system for the separation of the oestradiol epimers, and this system was adopted, since it met the requirements noted above, even though it was considered probable that a non-linear isotherm would result.

The ease of separation of oestriol from oestrone and oestradiol-17 $\beta$ by partition between water and benzene (cf. Bachman \& Pettit, 1941) rendered the use of chromatography unnecessary for this pur-

* Present address : Department of Metabolism, Montreal General Hospital, Montreal, Canada. pose. Oestriol was removed from the benzene solution of phenols and neutrals with water (Bauld, $1954 a$ ) and separated from the hydrophilic contaminants in this fraction by a partition chromato. gram with $70 \%$ methanol-ethylene dichloride, a solvent system discovered empirically.

The factors influencing the elution pattern of both chromatograms were investigated in detail.

\section{METHODS}

\section{Purification of materials}

Reagents used were A.R. unless otherwise stated. The final distillation of solvents was done in all-glass apparatus.

Benzene. This was refluxed for $30 \mathrm{~min}$. with $\mathrm{H}_{2} \mathrm{SO}_{4}$ (50 ml./1.), washed with $\mathrm{N}-\mathrm{NaOH}$ (B.P.) $(4 \times 0.1$ vol.), water (to neutrality), dried over anhydrous $\mathrm{Na}_{2} \mathrm{SO}_{4}$, and distilled.

Ethylene dichloride. This reagent (I.C.I., metal or stoneware containers) was washed with $\mathrm{N}-\mathrm{NaOH}$ (B.P.) $(3 \times 0.1$ vol.), water (to neutrality), dried over anhydrous $\mathrm{Na}_{8} \mathrm{SO}_{4}$, distilled, and redistilled within $24 \mathrm{hr}$. of use.

Methanol (I.C.I. refined). This was refluxed for $16-20 \mathrm{hr}$. with $\mathrm{NaOH}$ pellets $(5 \%, w / v)$ and $\mathrm{Zn}$ dust $(5 \%, w / v)$ and distilled twice.

Celite 535 (Johns Manville and Co. Ltd., London). This was partially calcined at $400^{\circ}$ for $4 \mathrm{hr}$., stirred with an excess of $\mathrm{HCl}$ and allowed to stand overnight. The solid was washed with water until the washings were free of $\mathrm{Cl}^{-}$ ( $\mathrm{AgNO}_{3}$ test), $\mathrm{Fe}^{8+}\left(\mathrm{SCN}^{-}\right.$test), and the $\mathrm{pH}$ was that of distilled water (glass electrode). The material was then dried at $110^{\circ}$ for $48 \mathrm{hr}$., cooled in a vacuum desiccator and stored in containers with tightly fitting glass stoppers. 